International Journal of Current Microbiology and Applied Sciences

ISSN: 2319-7706 Volume 9 Number 9 (2020)

Journal homepage: http://www.ijcmas.com

Original Research Article

https://doi.org/10.20546/ijcmas.2020.909.328

\title{
Post-harvest Management of Orchid Spikes and Florets
}

\author{
L. C. De* \\ ICAR-NRC for Orchids, Pakyong, Sikkim, India \\ *Corresponding author
}

\section{A B S T R A C T}

Keywords

Orchids, Cut flowers, Florets, Post-harvest, Vase life

\section{Article Info}

Accepted:

18 August 2020

Available Online:

10 September 2020
Orchids are consistently ranked among the best sellers in the global potted plant trade and also comprise $c$. $10 \%$ of all fresh cut flowers traded internationally. The orchids have taken a significant position in cut flower industry due to its attractiveness, long shelf life, high productivity, right season of bloom, and easy packing and transportation but lack a complete information module starting from pre-harvest to harvest and subsequently postharvest techniques including cooling, pulsing, impregnation, bud opening, holding solutions, storage, packaging, drying and transportation of different commercial genera of orchids. In the present investigation, the works on post-harvest technologies of cut spikes and florets of different orchid genera and species have been carried out.

\section{Introduction}

Orchids are the second largest families of flowering plants (Willis, 2017) and are globally distributed. Till date, 29199 species have been identified and accepted (Govaerts et al., 2017). One of the best-known plant groups in the global horticultural and cut flower trades (De, 2015; FloraHolland, 2015), orchids are also harvested, grown and traded for a variety of purposes, including as ornamental plants, medicinal products and food. Most popular global orchid trade is in artificially propagated cut flowers and plants grown under controlled conditions. During the period of 1996 to 2015, Taiwan and Thailand were the largest exporters, with most plants sent to South Korea (40\%), the USA (27\%) and Japan (20\%) (UNEP-WCMC, 2017). Orchids are consistently ranked among the best sellers in the global potted plant trade (Flora Holland, 2015; USDA, 2016) and also comprise c. $10 \%$ of all fresh cut flowers traded internationally (De, 2015). This represents an economically significant global trade, with exports of potted orchids from the Netherlands alone valued at almost $€ 500$ million in 2015 (Flora Holland, 2015). The 
largest areas of production are found in Thailand, Taiwan, The Netherlands and Japan, with demand for both potted and cut flowers growing in economic value annually (Hanks, 2015). Thailand, for example, sells roughly half of the orchids it produces in the domestic market (Thammasiri, 2015). Important orchid genera used as potted plants in the international market are Phalaenopsis, Oncidium, Cymbidium, Paphiopedilum, Dendrobium, Cattleya, Ascocenda, Vanda, Brassia, Miltonia and Epidendrum (Lopez and Runkle, 2005). Several local species of Ascocentrum, Calanthe, Cymbidium, Dendrobium, Paphiopedilum and Vanda, etc. are in great demand in international market for breeding materials (Kumar and Sheela, 2007). The orchids have taken a significant position in cut flower industry due to its attractiveness, long shelf life, high productivity, right season of bloom, and easy packing and transportation but lack a complete information module starting from pre-harvest to harvest and subsequently postharvest techniques including cooling, pulsing, impregnation, bud opening, holding solutions, storage, packaging and transportation of different commercial genera of orchids. In the present investigation, the works on post-harvest technologies of different orchid genera have been carried out.

\section{Materials and Methods}

Experiment No-1: Evaluation of cut spikes of different species and hybrids of orchids

Species: Lycaste spp., Phaius tankervillae, Vanda coerulea, Cymbidium tracyanum, $C$. elegans, C. cochleare, $C$. pendulum, $C$. lowianum, C. iridioides, Zygopetalum intermedium, Renanthera imschootiana, Vanda tessellata, Vanda stangeana.

Hybrids: Cymbidium, Dendrobium, Phalaenopsis, Mokara, Aranda, Oncidium, Paphiopedilum
Experimental Design: CRD

No of replication: 5 .

Observations: Days to first floret opening, diameter of first floret, spike length, No of florets/spike, rachis length, changes in fresh weight, total water uptake, days to last floret opening, senescence of last floret

Experiment No -2: Post-harvest life of Cymbidium hybrids as affected by different stages of harvest maturity

Miniature Cym. 'Sun Gold': S - 30-39cm, M- 40-49cm, L- 50-59 cm, XL- >60cm

Standard Cym, 'H.C. Aurora': A- 75-80cm, AA- $81-90 \mathrm{~cm}$, AAA- $>90 \mathrm{~cm}$

Intermediate Cym. 'PCMV': A- 60-64cm, AA- $65-69 \mathrm{~cm}$, AAA- $70-74 \mathrm{~cm}$

Experimental Design: CRD

No of replication: 5

Observations: Days to first floret opening, diameter of first floret, spike length, No of florets/spike, rachis length, changes in fresh weight, total water uptake, days to last floret opening, senescence of last floret

Experiment-3: Evaluation of Dendrobium hybrids at different stages of harvest maturity Stages of harvest

S1: Bud stage, S2: $25 \%$ open stage, S3: $50 \%$ open stage, S4: $100 \%$ open stage

Experimental Design: CRD

No of replication: 5

Observations: Days to first floret opening, diameter of first floret, No of partially opened florets/spike, No. of half opened florets/spike, No. of unopened florets/spike, rachis length, 
changes in fresh weight, total water uptake, days to last floret opening, senescence of last floret.

Experiment No-4: Standardization of harvesting stages in Cymbidium hybrid 'Pine Clash Moon Venus'

Stage I : Loose bud stage, Stage II : One bud opened stage, Stage III: Two buds opened stage, Stage IV: 3-4 buds opened stage, Stage V: Fully opened stage.

Experiment No-5: Standardization of pulsing solutions for cymbidium hybrids 'Pine Clash Moon Venus'

$\mathrm{T}_{0}$ : Control (Distilled water), $\mathrm{T}_{1}$ : Sucrose $(5 \%), \mathrm{T}_{2}$ : Sucrose $(8 \%), \mathrm{T}_{3}$ : Sucrose $(10 \%)$, $\mathrm{T}_{4}$ : 8-HQS (200 ppm), T $:$ Sucrose $(10 \%)+8-$ HQS (200 ppm), T 6 : Sucrose $(10 \%)+8-\mathrm{HQS}$ $(200 \mathrm{ppm})+\mathrm{BA}(50 \mathrm{ppm}), \mathrm{T}_{7}$ : AOA (1mM). Pulsing duration: $2,4 \& 6$ hours.

Experiment No-6: Post-harvest life of Cymbidium hybrid 'PCMV' and Phalaenopsis as influenced by impregnation

$\mathrm{T}_{0}$ : Control (Distilled water), $\mathrm{T}_{1}: \mathrm{AgNO}_{3}$ (1000 ppm) for 15 minutes, $\mathrm{T}_{2}: \mathrm{AgNO}_{3}(1500$ ppm) for 15 minutes, $\mathrm{T}_{3}: \mathrm{CoCl}_{2}(1000 \mathrm{ppm})$ for 15 minutes, $\mathrm{T}_{4}$ : $\mathrm{CoCl}_{2}(1500 \mathrm{ppm})$ for 15 minutes, $\mathrm{T}_{5}: \mathrm{NiCl}_{2}(1000 \mathrm{ppm})$ for 15 minutes, $\mathrm{T}_{6}$ : $\mathrm{Ni} \mathrm{Cl}_{2}(1500 \mathrm{ppm})$ for 15 minutes.

Experiment No-7: Effect of chemical preservatives on vase life of Cymbidium orchids cv. Pine Clash Moon Venus'

$\mathrm{T}_{0}$ : Distilled water, $\mathrm{T}_{1}$ : Glucose $(4 \%), \mathrm{T}_{2}$ : Sucrose (4\%), $\mathrm{T}_{3}: \mathrm{AgNO}_{3}(50 \mathrm{ppm}), \mathrm{T}_{4}: 8-$ HQS (200 ppm), T : Physan (200 ppm), $\mathrm{T}_{6}$ : $\mathrm{Al}_{2} \quad\left(\mathrm{SO}_{4}\right)_{3}, \mathrm{~T}_{7}$ : Aspirin (200 ppm), $\mathrm{T}_{8}$ : Glucose (4\%) + HQS (200 ppm), T: Sucrose $(4 \%)+$ HQS (200 ppm).
Experiment No-8: Standardization of bud opening chemicals for Cymbidium and Dendrobium orchids

$\mathrm{T}_{0}$ : Distilled water, $\mathrm{T}_{1}$ : Glucose/Sucrose $(4 \%)$ $+\mathrm{Al}_{2}\left(\mathrm{SO}_{4}\right)_{3}(100 \mathrm{ppm}), \mathrm{T}_{2}$ : Glucose/Sucrose $(4 \%)+8$-HQS $(200 \mathrm{ppm}), \quad \mathrm{T}_{3}$ : Glucose/Sucrose (4\%) + N:P:K(200: 200: $200)+$ Aspirin $(200 \quad \mathrm{ppm}), \quad \mathrm{T}_{4}$ : Glucose/Sucrose (4\%) + Aspirin (100 ppm), $\mathrm{T}_{5}$ : Glucose/Sucrose $(4 \%)+\mathrm{Ca}\left(\mathrm{NO}_{3}\right)_{2}(1 \%)$, $\mathrm{T}_{6}$ : Glucose/Sucrose $(4 \%)+$ Citric acid $(200$ $\mathrm{ppm})+\mathrm{Ag} \quad \mathrm{NO}_{3} \quad(50 \quad \mathrm{ppm}), \quad \mathrm{T}_{7}$ : Glucose/Sucrose (4\%) + Boric acid (200 $\mathrm{ppm})+\mathrm{KCl}(5 \mathrm{mM}), \mathrm{T}_{8}$ : Glucose/Sucrose $(4 \%)+\mathrm{Ag} \mathrm{NO}$ (50 ppm) + 8-HQS (200 ppm), $\mathrm{T}_{9}$ : Glucose/Sucrose $(4 \%)+\mathrm{BA}(50$ ppm $)+$ 8-HQS (200 ppm), $\mathrm{T}_{10}$ : Glucose/Sucrose (4\%) + N:P:K(200: 200: 200) + Aspirin (200 ppm), $\mathrm{T}_{11}$ : STS pulsing $(4 \mathrm{mM})$ for $10 \mathrm{~min}+8$-HQS $(200 \mathrm{ppm})+$ Glucose/Sucrose (4\%), $\mathrm{T}_{12}$ : Glucose/Sucrose $(4 \%)+0.5 \mathrm{mM}$ AOA.

Observations to be recorded: Vase life, physiological changes in weight, longevity of first floret, water uptake, changes in fresh weight, bud opening, percentage of flower dropping.

Experiment No-9: Post-harvest life of Cymbidium hybrid 'PCMV' as influenced by cane sugar

$\mathrm{T}_{0}$ : Control (Distilled water), $\mathrm{T}_{1}$ : Cane sugar $(2 \%), \mathrm{T}_{2}$ : Cane sugar $(4 \%), \mathrm{T}_{3}$ : Cane sugar $(8 \%)$

Experiment No-10: Effect of chemical preservatives on vase life of Cymbidium orchids cv. PCMV

$\mathrm{T}_{0}$ : Distilled water, $\mathrm{T}_{1}: 2 \%$ sucrose $(2 \%)+$ $100 \mathrm{ppm} \mathrm{Al} \mathrm{Al}_{2}\left(\mathrm{SO}_{4}\right)_{3}, \mathrm{~T}_{2}: 2 \%$ sucrose +100 ppm Ca $\left(\mathrm{NO}_{3}\right)_{2}, \mathrm{~T}_{3}: 2 \%$ sucrose +8 -HQS $(200$ ppm), $\mathrm{T}_{4}: 2 \%$ sucrose +25 ppm BA, $\mathrm{T}_{5}: 2 \%$ sucrose +100 ppm salicylic acid, $\mathrm{T}_{6}: 2 \%$ sucrose. 
Experiment No-11: Evaluation and biochemical analysis of backbulbs and mature bulbs of Cymbidium hybrids

Experiment No. 12: Effect of chemicals on vase life of Dendrobium orchids at different stages of harvesting maturity

$\mathrm{T}_{1}$ : Sugar $(4 \%)+$ Salicylic acid $(100 \mathrm{ppm})$, $\mathrm{T}_{2}$ : Sugar $(4 \%)+\mathrm{Ca}\left(\mathrm{NO}_{3}\right)_{2}(1 \%), \mathrm{T}_{3}$ : Sugar $(4 \%)+\mathrm{Al}_{2}\left(\mathrm{SO}_{4}\right)_{3}(100 \mathrm{ppm}), \mathrm{T}_{4}:$ Sugar $(4 \%)$ +8 -HQS (200 ppm), $\mathrm{T}_{5}$ : Sugar (4\%) + $\mathrm{K}_{2} \mathrm{SO}_{4}$ $(0.5 \%), \mathrm{T}_{6}:$ Sugar $(4 \%), \mathrm{T}_{7}:$ Control (Distilled water)

Experimental Design: CRD No. Of Replication: 5

Observations: Changes in fresh weight, Days to senescence of first floret, days to senescence of last floret, No. of partially opened buds, No. of half opened buds and number of unopened buds, solution uptake.

Experiment No. 13. Evaluation of keeping quality of tropical and subtropical orchid hybrids as effected by packing materials

\section{Orchid hybrids}

Aranda, Mokara, Oncidium, Dendrobium, Vanda, Cattleya

Packing materials: Cotton swab, foam, Plastic vial

Observations: Changes in fresh weight, longevity (days)

Experiment No-14: Effect of packaging materials on post-harvest life of Cymbidium hybrid 'PCMV'

Packaging materials: T1: Polypropylene150 gauge; T2: Cellophane; T3: LDP-100 gauge; T4: HDP -150 gauge; T5: Newspaper; T6: Control (Without packing).

Experimental Design: CRD

No. of Replication: 5
Observations: Changes in fresh weight, Total water uptake, longevity of first floret and longevity of last floret.

Experiment No-15: Evaluation of terrestrial orchids for vase life

Stage of harvest in Phaius tankervilleae: Loose bud stage, one bud open stage, two buds opened stage, 3 buds open stage, 5 buds open stage, 7 buds open stage, 9 buds open stage.

Stage of harvest in Epidendrum: One bud open, all floret open except top 5 buds, all florets open except top 10 buds.

Observations: Changes in fresh weight, diameter of first floret, Longevity of first floret, longevity of last floret and solution uptake.

Experiment No. 16: Post harvest management of orchid florets

Orchid genera: Cymbidium, Cattleya, Phalaenopsis

Packing materials: Cellophane papers

Experiment No. 17: Enhancement of keeping quality of loose florets of orchids

Orchid genera: Bamboo orchid, Phalaenopsis, Cymbidium, Epidendrum

Chemical treatments: $\mathrm{Al}_{2}\left(\mathrm{SO}_{4}\right)_{3}$ at $0.1 \%, 0.2 \%, 0.4 \%, 0.6 \%, 0.8 \%$ and $1.0 \%$ solutions and control (water)

Experiment No. 18: Flower drying in orchids

Orchid hybrids and species: Cattleya, Cymbidium, Phalaenopsis, Dendrobium, Oncidium, Paphiopedilum, Aranda, Mokara, Coelogyne flaccida, Coelogyne cristata, 
Dendrobium nobile, Dendrobium williamsonii, Dendrobium aphyllum, Vanda teres, Dendrobium moschatum, Arundina graminifolia, Epidendrum spp.

Drying techniques: Embedded drying in sand, borax, silica gel in oven and under room conditions

\section{Results and Discussion}

\section{Evaluation of cut spikes and florets of different species and hybrids of orchids for vase life}

Orchids species namely Cymbidium iridioides, Zygopetalum intermedium, Phaius tankervillae and Lycaste species were evaluated for their vase life and found out that Cymbidium iridioides is having the vase life of 29.50 days followed by $C$. cochleare (29 days), $C$. tracyanum (24 days), C. elegans (10 days) and Zygopetalum intermedium is having the vase life of 18.10 days. Phaius tankervillae is having 24.20 days and Lycaste sp having 9 days of vase life. Renanthera imschootiana had vase life of 24 days, Vanda tessellata 16 days and Vanda stangeana 10 days.

Cut spikes of Cymbidium hybrids namely Pine Clash Moon Venus, Red Princess, White Beauty; H.C. Aurora, Sun Gold, Ensikhan, Florance, Valley Legand and Platinum Gold were evaluated for their post harvest life. Cymbidium hybrid Florance is having the highest vase life of 53.66 days followed by White beauty 53.05 days. Lowest vase life was noticed in Platinum Gold (22.44 days).

In another experiment, cut spikes of Cymbidium hybrids namely 'Baltic Glacier Mint Ice', 'Sleeping Nymph', and 'Valley Pink Inspiration' and 'Valley Flower Powder Puff' were evaluated for their post harvest life. Among the hybrids highest vase life was recorded in 'Sleeping Nymph' 56.90 days followed by 'Valley Flower Powder Puff' (52.86 days) and Baltic Glacier Mint Ice (41.81 days). Vase life was lowest in 'Valley Pink Inspiration' 29.00 days.

Out of cut spikes of ten Cymbidium hybrids evaluated, Bob Marlin Lucky' had shown maximum longevity of first floret (51 days) and vase life (57 days) followed by 'Fire Storm Blaze' (47 days \& 53 days). Minimum longevity of first floret (21 days) was recorded in Hana Akari and minimum vase life (35 days) recorded in 'Rocky Creek Pebbles' and 'Hee Haw Sagun'.

In cut spikes of Mokara hybrids, vase life ranges from 17 days (Walter Ouame White) to 58 days (Jitti Orange), Aranda from 13 days (Thailand Sunspot) to 45 days (Propine Spot), Vanda from 12.5 days (Pat D ) to 41 days (V. Sirilak x V. Thongchai Gold' ) and in Oncidium from 20 days (Taka Yellow ) to 38 days (Wild Cat Bob Cat).

In Mokara, 'Walter Oumae White', cut spikes harvested at all florets opened except top 4-5 buds had maximum vase life (18.5 days) followed by all florets opened except one bud (17 days) and all florets opened (13 days.)

In Phalaenopsis, cut spikes of 11 hybrids evaluated and 'Manchester' had highest vase life (62.2 days).

Out of 9 advance lines and 2 species of Paphiopedilum evaluated, highest vase life was recorded in PL x PW-28 (79 days) followed by Sheetal -1 (52 days) and lowest in PL x PW 39 (15 days).

In Cymbidium, out of 15 hybrids evaluated for florets, 30-40 days vase life were recorded in Hazel Fay Tangerine, Levis Duke Bella Vista, Everett Stockstill Bullai, Valley Teaser, and Samurai Hee Haw Sagun; 41-50 days vase life recorded in Fire Strom Blaze, Rocky Creek 
Pebbles, Bob Marlin Lucky, Satrun Doll, Sun Gold and MT Perfection and 51-60 days vase life recorded in Valley Legend Steff, H.C. Aurora and Pine Clash Moon Venus (PCMV).

In Cymbidium 'PCMV', fully open florets had maximum vase life (48 days) followed by half open floret (41 days with $100 \%$ opening), loose bud florets (35 days with $50 \%$ opening) and tight bud florets (26 days with $25 \%$ opening).

Post-harvest life of Cymbidium hybrids as affected by different stages of harvest maturity

In Cymbidium, out of four different stages of harvest maturity of Miniature hybrid 'Sun Gold', three different stages of standard hyb. 'H.C. Aurora', and three different stages of intermediate hyb.'PCMV', stage-III (spike length: > 90cm) of standard hybrid had maximum vase life (59 days).

Among different types of Cymbidium hybrids, vase life ranges from 30-34 days in miniature, 35-37 days in intermediate and 5559 days in standard hybrids. The enhanced vase life of Cymbidium due to stages of harvest was explained by De et al, 2014.

Evaluation of Dendrobium hybrids at different stages of harvest maturity

At bud stage, out of 12 hybrids of Dendrobium evaluated, maximum vase life recorded in Den. Big White Jumbo (45 days) and maximum per cent of fully opened flowers in Den. Kating Dang (45\%).

At $50 \%$ opened stage, highest vase life recorded in Den. Big White Jumbo (60 days) and more than $90 \%$ fully opened flowers recorded in Den. Big White Jumbo, Thongchai Gold and Lervia.
Standardization of harvesting stages in Cymbidium hybrid 'Pine Clash Moon Venus'

In Cymbidium hyb. 'PCMV', out of five different stages of harvest maturity, two buds opened stage had maximum vase life (66.8 days) and floret opening followed by 3-4 buds opened stage (64.8 days) and minimum with loose bud stage (59 days). Maximum water uptake was recorded in two buds opened stage (46ml). Percentage of flower bud opening ranges from $81 \%$ (loose bud stage) to $100 \%$ (3-4 buds opened stage). The stage $\mathrm{V}$ i..e. fully opened stage had maximum reduction in weight ( $24.6 \mathrm{~g})$.

Standardization of pulsing solutions for Cymbidium hybrids 'Pine Clash Moon Venus'

Among the different pulsing solutions used sucrose at $5 \%$ for 2 hours increased the vase life of flower (56 days) followed by Sucrose @ 8\% (54.78 days).

Post-harvest life of Cymbidium hybrid 'PCMV' and Phalaenopsis as influenced by impregnation

In the experiment on impregnation of cut spikes of Cym. 'PCMV', maximum water uptake was recorded with $\mathrm{CoCl}_{2}$ (1000ppm) for 15 minutes $(38 \mathrm{ml})$ followed by $\mathrm{CoCl}_{2}$ (1500ppm) for 15 minutes $(35 \mathrm{ml})$. Highest longevity was recorded with $\mathrm{CoCl}_{2}$ (1000ppm) for 15 minutes (46 days) followed by $\mathrm{CoCl}_{2}$ (1500ppm) for 15 minutes (44days) over control (39 days).

In Phalaenopsis 'Detroit', among five impregnation treatments $\mathrm{CoC}_{12} \quad(1000$ ppm) for 45 minutes had maximum vase life (75.6 days ) followed by $\mathrm{NiCl} 2$ (1000 ppm) for 45 minutes (62 days) over control ( 45 days). 
Effect of chemical preservatives on vase life of Cymbidium orchids cv. Pine Clash Moon Venus'

Experiment on the effect of sucrose and antiethylene agents on vase life of cymbidium flowers with damaged pollinia was carried out with twelve different chemicals in Cymbidium Hybrid 'PCMV'. Treatments were given in two different forms like pulsing and holding to the flowers with pollinia and flowers without pollinia. Among the different treatments pulsing of flowers with $5 \%$ sucrose followed by $150 \mathrm{ppm}$ 8HQS increased the vase life of flowers with pollina (49.33 \& 46.33 days) and without pollinia (44.00 \& 41.67 days). In case of holding solutions, 8HQS $150 \mathrm{ppm}$ increased the vase life of flowers with pollinia (48.33 days) followed by 8 HQS 200 ppm (46.80 days). 8 HQS 200 ppm increased the vase life (36.67 days) of flowers without pollinia.

\section{Standardization of bud opening chemicals for Cymbidium and Dendrobium orchids}

Reducing sugar analysis was carried out in Dendrobium hybrid 'Thanchai Gold'. Three stages of flowers like opened flowers, half opened flowers and bud has taken for analysis. It was found out that opened flower contains $29.00 \%$, half opened flower contains $28.25 \%$ and buds contain $16.17 \%$ of reducing sugars.

In Cymbidium hybrid 'Ensikhan', chemicals like $4 \%$ sucrose $+1 \% \mathrm{Ca}\left(\mathrm{NO}_{3}\right)_{2}, 4 \%$ sucrose $+100 \mathrm{ppm}$ salicylic acid and $4 \%$ sucrose $+\mathrm{Al}_{2}(\mathrm{SO} 4)_{3}$ were found effective for opening of maximum number of buds, least bud drop and highest vase life (27days) over control(19 days in distilled water).

Opening of tight buds of cut flowers of Cymbidium 'PCMV' was improved with all chemical treatments except control. Minimum duration (18 days) for opening of first floret was observed with Sugar 4\% +8 -HQS (200 ppm). The treatment combination of sugar $4 \%+$ Salicylic acid $200 \mathrm{ppm}$ had first floret with maximum diameter $(6.6 \mathrm{~cm})$. Per cent of half opened buds was recorded maximum $(30.7 \%)$ with sugar 4\% + 8-HQS (200 ppm) whereas per cent of fully opened buds was highest $(75 \%)$ in sugar $4 \%$ + Salicylic acid $200 \mathrm{ppm}$. In control, all flower buds dropped on $27^{\text {th }}$ days. Vase life of cut spikes was found maximum (45days) with sugar 4\% + Salicylic acid (200 ppm) followed by Sugar $4 \%+\mathrm{Al}_{2}\left(\mathrm{SO}_{4}\right)_{3}(100$ ppm) and sugar $4 \%+8$-HQS (200 ppm) (44 days) (Table 1). Bud opening, improved flower size and enhancement of vase life of tight bud cut flowers of Cymbidium orchids as treated with Sugar $4 \%$ + Salicylic acid (200 ppm) may be attributed to effect of salicylic acid as anti-transpirant by induction of stomatal closure or by blocking the conversion of a amino cyclopropane -1-carboxylic acid to ethylene (Leslie and Romani, 1986).

Changes in carbohydrate content of cut flowers of Cymbidium at senescence stage had shown significant variations starting from flower bud to flower opening stage. Highest content of carbohydrate $(140 \mathrm{mg} / \mathrm{g})$ was estimated at bud stage in fresh condition followed by at bud stage $(131 \mathrm{mg} / \mathrm{g})$ at senescence in control. Minimum carbohydrate content $(60 \mathrm{mg} / \mathrm{g})$ was observed with Sugar $4 \%+8-\mathrm{HQS}$ (200 ppm) followed by Sugar $4 \%+$ Salicylic acid $200 \mathrm{ppm})(64 \mathrm{mg} / \mathrm{g})$ (Table 2). Flower opening has been reported to be dependent on carbohydrate levels in the petals (Van Doorn et al., 1991b).

In Dendrobium hybrid 'Thongchai Gold', per cent of fully opened buds (66\%) was recorded maximum with sucrose $(4 \%)+$ $\mathrm{Ca}\left(\mathrm{NO}_{3}\right)_{2}$ (1\%) followed by sucrose (4\%) + acetyl acetic acid (100 ppm) (60\%). Longest vase life (36 days) was found 
with sucrose $(4 \%)+\mathrm{Al}_{2}\left(\mathrm{SO}_{4}\right)(100 \mathrm{ppm})$ followed by sucrose $(4 \%)+$ acetyl acetic acid (100 ppm) (33 days) (Table 3). Beneficial effect of 8-HQS on bud opening of Dendrobium cutflowers was reported by Ketsa et al, 2001.

\section{Post-harvest life of Cymbidium hybrid 'PCMV' as influenced by cane sugar}

In the experiment on the effect of cane sugar in holding solution on vase life of Cym. 'PCMV', out of four treatments $(0 \%, 2 \%$ cane sugar, $4 \%$ cane sugar and $8 \%$ cane sugar), $2 \%$ cane sugar had shown maximum depletion of stored carbohydrates, maximum longevity of first floret (54 days), zero per cent of flower dropping, maximum solution uptake $(24 \mathrm{ml})$ and highest vase life (61.2 days) followed by $4 \%$ cane sugar. $8 \%$ cane sugar had least longevity of first floret (27.2 days) and vase life (36.2 days).

Effect of chemical preservatives on vase life of Cymbidium orchids cv. PCMV and Zygopetalum

In the experiment, out of 8 different chemicals for holding chemicals on postharvest life of Cym. 'PCMV', longevity of first floret was recorded maximum with $\mathrm{BA}$ (25 ppm) (49.2 days) followed by $\mathrm{Al}_{2}\left(\mathrm{SO}_{4}\right)_{3}$ (100 ppm) (45.2 days). Maximum vase life (54.8 days) was found with $\mathrm{Ca}\left(\mathrm{NO}_{3}\right)_{2}(100$ $\mathrm{ppm})$ followed by $\mathrm{Al}_{2}\left(\mathrm{SO}_{4}\right)_{3}(100 \mathrm{ppm})(53.4$ days). Solution uptake $(33 \mathrm{ml})$ was observed maximum with $\mathrm{Al}_{2}\left(\mathrm{SO}_{4}\right)_{3}(100 \mathrm{ppm})$ and 8HQS(200 ppm).

In Cymbidium hybrid, 'PCMV', out of six treatment combinations, $2 \%$ sucrose +200 ppm 8-HQS had shown maximum longevity of first floret (66 days) and vase life (77.6 days) followed by $2 \%$ sucrose $+100 \mathrm{ppm}$ $\mathrm{Al}_{2}\left(\mathrm{SO}_{4}\right)_{3}$ (65.4 days \& 77.4 days) over control in tap water ( 33 days $\& 61.4$ days).

In Cymbidium hybrid, 'PCMV', treatment with $2 \%$ sucrose $+100 \mathrm{ppm}$ salicylic acid showed maximum longevity (63 days) of cut spikes in fully opened stage followed by one bud opened stage (62 days) whereas 2\% sucrose $+100 \mathrm{ppm} \mathrm{Al}_{2}\left(\mathrm{SO}_{4}\right)_{3}$ had highest longevity of cut spikes (56 days) at two buds opened stage followed by fully opened stage (55.6 days).

Treatment with $2 \%$ sucrose $+100 \mathrm{ppm}$ $\mathrm{Al}_{2}\left(\mathrm{SO}_{4}\right)_{3}$ enhanced post-harvest life of Zygopetalum cut flowers to the extent of 15 days over control 10 days in tape water.

Evaluation and biochemical analysis of backbulbs and mature bulbs of Cymbidium hybrids

Out of sixteen hybrids of cymbidium orchids, fourteen hybrids came into flowering. Maximum width $(9.0 \mathrm{~cm})$ and length $(14.5 \mathrm{~cm})$ of flowering pseudobulb and spike length $(81 \mathrm{~cm})$ was recorded in 'Fire Storm Blaze'. Longevity of flowers on plants was recorded highest in 'Caripepper Peachy Keen'(70 days). In backbulbs, carbohydrate content ranges from $70 \mathrm{mg} / \mathrm{g}$ in 'Pink' to $152 \mathrm{mg} / 100 \mathrm{~g}$ in 'Fire Storm Blaze' whereas in flowering pseudobulbs it varied from $88 \mathrm{mg} / \mathrm{g}$ in 'Pink' to $180 \mathrm{mg} / 100 \mathrm{~g}$ in 'Fire Storm Blaze'. Fire storm Blaze had maximum chlorophyll content $(71.20 \mathrm{mg} / 100 \mathrm{~g})$ followed by 'Hazel Fay Tangerine' $(58.80 \mathrm{mg} / 100 \mathrm{~g})$ and minimum in 'Red' $(19.20 \mathrm{mg} / 100 \mathrm{~g})$. 
Table.1 Effect of chemicals on bud opening in Cymbidium hyb. 'Pine Clash Moon Venus'

\begin{tabular}{|c|c|c|c|c|c|}
\hline Treatment & $\begin{array}{c}\text { Days to first } \\
\text { floret } \\
\text { opening }\end{array}$ & $\begin{array}{l}\text { Diameter of } \\
\text { first floret } \\
(\mathrm{cm})\end{array}$ & $\begin{array}{l}\text { Per cent of } \\
\text { half opened } \\
\text { buds }\end{array}$ & $\begin{array}{l}\text { Per cent of } \\
\text { Fully } \\
\text { opened } \\
\text { buds }\end{array}$ & $\begin{array}{c}\text { Vase life } \\
\text { (Days) }\end{array}$ \\
\hline $\begin{array}{l}\text { Distilled } \\
\text { water }\end{array}$ & --- & ---- & 0 & 0 & 27 \\
\hline Sugar 4\% & 20 & 5.1 & 5.8 & 44 & 37.8 \\
\hline $\begin{array}{l}\text { Sugar } 4 \%+ \\
\mathrm{Al}_{2}\left(\mathrm{SO}_{4}\right)_{3}(100 \\
\text { ppm) }\end{array}$ & 21 & 5.4 & 0 & 57 & 44 \\
\hline $\begin{array}{l}\text { Sugar } 4 \%+ \\
\text { 8-HQS } \quad(200 \\
\text { ppm) }\end{array}$ & 18 & 5.5 & 30.7 & 53.8 & 44 \\
\hline $\begin{array}{l}\text { Sugar } 4 \%+ \\
\text { Salicylic acid } \\
(200 \text { ppm })\end{array}$ & 21 & 6.6 & 0 & 75 & 45 \\
\hline $\begin{array}{ll}\text { Sugar } & 4 \%+ \\
\mathrm{Ca} & \left(\mathrm{NO}_{3}\right)_{2} \\
(1 \%) & \end{array}$ & 25 & 4.85 & 2 & 22.8 & 37.8 \\
\hline $\begin{array}{l}\text { Sugar } 4 \%+ \\
\text { Boric acid } \\
200 \text { ppm + } \\
\mathrm{K}_{2} \mathrm{SO}_{4} \\
(2 \mathrm{mM})\end{array}$ & 20.5 & 5.5 & 6.25 & 25 & 36.2 \\
\hline CD $_{5 \%}$ & 2.86 & 0.32 & 0.34 & 2.55 & 3.10 \\
\hline
\end{tabular}

Table.2 Changes in total carbohydrates as affected by effect of chemicals on bud opening of Cym. 'PCMV' harvested at bud stage

\begin{tabular}{|c|c|c|c|}
\hline Treatment & Sample & Stage & $\begin{array}{l}\text { Carbohydrate } \\
\text { content }(\mathrm{mg} / \mathrm{g})\end{array}$ \\
\hline & Bud & Fresh & 140 \\
\hline Distilled water & Bud & Senescence & 131 \\
\hline Sugar $4 \%$ & Flower & Senescence & 96 \\
\hline Sugar $4 \%+\mathrm{Al}_{2}\left(\mathrm{SO}_{4}\right)_{3}(100 \mathrm{ppm})$ & Flower & Senescence & 64 \\
\hline Sugar 4\% + 8-HQS (200 ppm) & Flower & Senescence & 60 \\
\hline Sugar 4\% + Salicylic acid 200 ppm) & Flower & Senescence & 64 \\
\hline Sugar $4 \%+\mathrm{Ca}\left(\mathrm{NO}_{3}\right)_{2}(1 \%)$ & Flower & Senescence & 70 \\
\hline $\begin{array}{l}\text { Sugar } 4 \%+\text { Boric acid } 200 \text { ppm + } \\
\mathrm{K}_{2} \mathrm{SO}_{4}(2 \mathrm{mM})\end{array}$ & Flower & Senescence & 76 \\
\hline
\end{tabular}


Table.3 Effect of chemicals in bud opening in Dendrobium 'Thongchai Gold'

\begin{tabular}{|l|c|c|c|l|}
\hline Treatments & $\begin{array}{c}\text { \% of bud } \\
\text { swelling }\end{array}$ & $\begin{array}{c}\text { \% of half } \\
\text { opened buds }\end{array}$ & $\begin{array}{c}\text { \% of fully } \\
\text { opened buds }\end{array}$ & Vase life (days) \\
\hline Distilled water & 10 & 0 & 0 & 21 \\
\hline $\begin{array}{l}\text { Sucrose (4\%) } \\
+\mathrm{Al}_{2}\left(\mathrm{SO}_{4}\right)_{3}(100 \mathrm{ppm})\end{array}$ & 11 & 22.2 & 33.3 & 36 \\
\hline $\begin{array}{l}\text { Sucrose }(4 \%)+\mathrm{HQS}- \\
200 \text { ppm }\end{array}$ & 0 & 11 & 44.4 & 27 \\
\hline $\begin{array}{l}\text { Sucrose(4\%)+ Acetyl } \\
\text { salicylic acid (100ppm) }\end{array}$ & 10 & 20 & 60 & 33 \\
\hline $\begin{array}{l}\text { Sucrose(4\%)+ } \\
\text { Ca(NO })_{2}(1 \%)\end{array}$ & 8.5 & 8.5 & 66 & 32 \\
\hline
\end{tabular}

Table.4 Longevity of florets in Cymbidium hybrids

\begin{tabular}{|c|c|c|c|c|c|}
\hline Hybrid & $\begin{array}{l}\text { Packed } \\
\text { florets }\end{array}$ & $\begin{array}{l}\text { Unpacked } \\
\text { florets }\end{array}$ & Hybrid & $\begin{array}{l}\text { Packed } \\
\text { florets }\end{array}$ & $\begin{array}{l}\text { Unpacked } \\
\text { florets }\end{array}$ \\
\hline Cym. H.C. Aurora & 25 days & 10 days & $\begin{array}{l}\text { Cym. Valley } \\
\text { Legend Steff }\end{array}$ & 26 days & 21 days \\
\hline $\begin{array}{l}\text { Cym. Hazel Fay } \\
\text { Tangerine }\end{array}$ & 25 days & 19 days & Cym. BGMI & 26 days & 21 days \\
\hline $\begin{array}{l}\text { Cym. Bob Marlin } \\
\text { Lucky }\end{array}$ & 37 days & 15 days & $\begin{array}{l}\text { Cym. Samuari } \\
\text { Hee Haw Sagun }\end{array}$ & 26 days & 7 days \\
\hline Cym. Fire Storm & 35 days & 14 days & Cym. PCMV & 25 days & 7 days \\
\hline $\begin{array}{l}\text { Cym. C. Peachy } \\
\text { Keen }\end{array}$ & 39 days & 13 days & $\begin{array}{l}\text { Cym. rocky } \\
\text { Creek Pebbles }\end{array}$ & 31 days & 10 days \\
\hline Cym.WBSG & 33 days & 22 days & Cym. LDBV & 25 days & 14 days \\
\hline Cym. Soul Hunt 6 & 15 days & 9 days & & & \\
\hline
\end{tabular}

\section{Recommendations}

Stages oh harvest of orchids for enhanced vase life

\begin{tabular}{|c|c|c|c|}
\hline \multicolumn{4}{|c|}{ Stage of Harvest in orchids } \\
\hline $\begin{array}{l}\text { Orchid } \\
\text { hybrid }\end{array}$ & $\begin{array}{l}\text { Commercial stage of } \\
\text { haryest }\end{array}$ & \begin{tabular}{|l|} 
Spike \\
length (cm)
\end{tabular} & $\begin{array}{l}\text { Vase life } \\
-(-c l a p / 5)\end{array}$ \\
\hline Aranda & $50 \%$ bloom & $45-60 \mathrm{~cm}$ & 18-28 days \\
\hline Cattleya & $\begin{array}{l}2-4 \text { days before bud } \\
\text { open }\end{array}$ & $25-40 \mathrm{~cm}$ & 10- 20 days \\
\hline Cymbidium & $75 \%$ bloom & $60 \mathrm{~cm}-1.25 \mathrm{~m}$ & 55-60 days \\
\hline Dendrobium & $\begin{array}{l}\text { All flowers except top } \\
\text { bud }\end{array}$ & $40-60 \mathrm{~cm}$ & 14-21 days \\
\hline Oncidium & $80 \%$ bloom & $60 \mathrm{~cm}$ & 25-35 days \\
\hline Paphiopedilum & $\begin{array}{l}3 \text { to } 4 \text { days after } \\
\text { opening of flowers }\end{array}$ & $25-40 \mathrm{~cm}$ & $30-56$ days \\
\hline Phalaenopsis & Fully open flowers & $40-60 \mathrm{~cm}$ & $25-40$ days \\
\hline Vanda & Fully open flowers & $50-75 \mathrm{~cm}$ & 14- 30 days \\
\hline
\end{tabular}




\section{Post-harvest technology in Cymbidium}

\begin{tabular}{|c|l|l|}
\hline Sl.No. & \multicolumn{1}{|c|}{ Particulars } & \multicolumn{1}{|c|}{ Recommendations } \\
\hline $\mathbf{1 .}$ & $\begin{array}{l}\text { Evaluation of elite hybrids for } \\
\text { vase life }\end{array}$ & $\begin{array}{l}\text { Bob Marlin Lucky (57 days), Fire Strom Blaze } \\
(53 \text { days), Hazel Fay Tangerine (50 days), } \\
\text { Everett Stockstill Bullai (48 days), Caripepper } \\
\text { Peachy Keen (43 days), Hana Akari (41 days), }\end{array}$ \\
\hline Fire Storm Ruby (36 days)
\end{tabular}




\section{Post-harvest technology in Dendrobium}

\begin{tabular}{|c|c|c|}
\hline Sl.No. & Particulars & Recommendations \\
\hline 1. & $\begin{array}{l}\text { Evaluation of commercial hybrids } \\
\text { of Dendrobium for vase life }\end{array}$ & $\begin{array}{l}\text { Triple Pink ( } 40 \text { days), Emma White }(37 \\
\text { days), Madam Pompadour ( } 37 \text { days), } \\
\text { Erika ( } 34.8 \text { days), Ear Sakul ( } 33.5 \text { days), } \\
\text { Thongchai Gold ( } 30.4 \text { days), Big White } \\
\text { Jumbo ( } 29.5 \text { days), Kating Dang ( } 28 \\
\text { days), Lervia ( } 28 \text { days), Daang Saard } \\
\text { (27.5 days), Julie ( } 25 \text { days) }\end{array}$ \\
\hline 2. & $\begin{array}{l}\text { Best harvesting stage of } \\
\text { Dendrobium for maximum vase } \\
\text { life }\end{array}$ & $\begin{array}{l}50 \% \text { opened stage with } 60 \text { days of vase } \\
\text { life }\end{array}$ \\
\hline 3. & $\begin{array}{l}\text { Best bud opening of Dendrobium } \\
\text { for improved vase life }\end{array}$ & $4 \%$ Sucrose +100 ppm Salicylic acid \\
\hline 4. & $\begin{array}{l}\text { Best holding solution of } \\
\text { Dendrobium for improved vase } \\
\text { life }\end{array}$ & $\begin{array}{l}2 \% \text { sucrose }+200 \text { ppm ASA and } 2 \% \\
\text { glucose }+100 \text { ppm ASA were found as } \\
\text { best holding solutions for maximum vase } \\
\text { life ( } 80 \text { days) over control (without } \\
\text { treatment) ( } 48 \text { days). }\end{array}$ \\
\hline
\end{tabular}

Flower drying in orchids

\begin{tabular}{|c|c|c|}
\hline SI.No. & Species / varieties of orchids & Recommendations \\
\hline 1. & $\begin{array}{l}\text { Vanda teres, Dendrobium moschatum, } \\
\text { Arundina graminifolia, Den. 'Madam Pink', } \\
\text { Den. 'Lervia', Den. 'Abraham', Phal. 'Casa } \\
\text { Blanca', Phal. 'Detroit' and Oncidium 'Sweet } \\
\text { Sugar' }\end{array}$ & $\begin{array}{l}\text { Embedded drying with borax at } \\
50^{\circ} \mathrm{C} \text { in oven }\end{array}$ \\
\hline 2. & $\begin{array}{l}\text { Epidendrum spp., Cattleya bowringiana and } \\
\text { Cattleya hybrids, Phal. 'Ox Plum Rose x } \\
\text { Black Jack' and Den. 'Big White', Vanda } \\
\text { coerulea }\end{array}$ & $\begin{array}{l}\text { Embedded drying with borax at } \\
60^{\circ} \mathrm{C} \text { in oven }\end{array}$ \\
\hline 3. & $\begin{array}{l}\text { Coelogyne flaccida, Coelogyne cristata, } \\
\text { Dendrobium nobile, Dendrobium } \\
\text { williamsonii, Dendrobium aphyllum, Den, } \\
\text { 'Erika', Den. 'Big White } 4 \mathrm{~N} \text { ', Den. 'Bangkok } \\
\text { Blue', Phal.'Nagasaki' and Cym. 'Sungold'. }\end{array}$ & $\begin{array}{l}\text { Embedded drying with borax and } \\
\text { silica gel at } 55^{\circ} \mathrm{C} \text { in oven }\end{array}$ \\
\hline 4. & $\begin{array}{l}\text { Dendrobium, Phalaenopsis, Cattleya, } \\
\text { Cymbidium, Aranda, Mokara hybrids }\end{array}$ & $\begin{array}{l}\text { Perlite, Perlite }+ \text { borax and Perlite }+ \\
\text { Silica gel under room condition }(24- \\
\left.25^{\circ} \mathrm{C} \text { and } 75-79 \% \mathrm{RH}\right)\end{array}$ \\
\hline 5. & $\begin{array}{l}\text { Cattleya 'Guanmian } \\
\text { 'Lervia, Phalanopsis 'Vienna ', Dendrobium } \\
\text { tessellata, Oncidium 'Taka 'Yellow', } \\
\text { Phalanopsis 'Taida S.Red' }\end{array}$ & $\begin{array}{l}\text { Embedded drying with sand at } 50^{\circ} \mathrm{C} \\
\text { in oven }\end{array}$ \\
\hline
\end{tabular}


Effect of chemicals on vase life of Dendrobium orchids at different stages of harvesting maturity

In Den. 'Thongchai Gold', at $50 \%$ bud opened stage, treatment with $4 \%$ sucrose + $100 \mathrm{ppm} \mathrm{Al}_{2}\left(\mathrm{SO}_{4}\right)_{3}$ had maximum vase life (49 days) over control (35 days ).

Evaluation of keeping quality of tropical and subtropical orchid hybrids as effected by packing materials

In foam, longevity of cut spikes of Aranda ranges from 27 days (Propine spot) to 40 days (Thailand Sunspot), in Mokara, from 13 days (Happy Beauty) to 27 days (Walter Ouame White), in Oncidium, 17 days (Taka Yellow), in Dendrobium, 9 days (Lervia to Bangkok Blue (34 days), in Vanda, 9 days (Sansai Blue) to Prao Sky Blue (17 days)and in Cattleya, 10 days (Queen Sirikhit). In plastic vials, longevity of cut spikes of Aranda ranges from 22 days (Propine Spot) to 34 days (Thailand Sunspot), in Mokara, from 26 days (Kultana Gold) to 50 days (Happy Beauty), in Oncidium, from 20 days (Sweet Fragrance) to 27 days (Taka Yellow), in Dendrobium, from 21 days (Erika) to 58 days (Emma White), in Vanda, from 27 days (Pat D ) to 60 days (Prao Sky Blue) and in Cattleya 14 days (Queen Sirikhit).

Effect of packaging materials on postharvest life of cut spikes of different orchids

Out of five packaging materials used in Cymbidium hybrid 'PCMV', highest keeping quality was recorded with cellophane (56 days) followed by polypropylene (150 gauge) (54 days) and low density polyethylene (54 days) over control (50 days) without packing. Maximum water uptake was found with control $(35 \mathrm{ml})$ followed by newspaper packing $(34.2 \mathrm{ml})$.

In Cym. 'Sun Gold', packing of $25 \%$ bud open stage cut spikes with cellophane paper had maximum vase life (48 days) followed by $50 \%$ bud open stage (46 days).

In Cym. 'PCMV', packing of loose bud stage cut spikes with cellophane paper had maximum vase life (60 days) over control (49 days).

In Cym. 'Sleeping Nymph' the longevity of cut flowers of value added packed items had shown upto 33 days.

In Dendrobium, 'Emma White', Cellophane paper packaging of cut flowers had shown maximum vase life (30.3 days) over control (without packing) (17 days).

\section{Evaluation of terrestrial orchids for vase} life

In Phaius tankervilleae, out of seven harvest stages, cut flowers of loose bud stage had maximum vase life (33 days) and minimum at 9 buds opened stage (20 days).

In Epidendrum, cut flowers harvested at all florets opened stage except 5 buds showed maximum vase life (28 days) followed by all florets opened stage except top 10 buds (22 days.)

\section{Post harvest management of orchid florets}

In elite Cymbidium hybrids, longevity of cellophane paper packing of fully open florets ranges from 15 days (Soul Hunt 6) to 39 days (Caripepper Peachy Keen) over unpacked florets i.e. 9 days and 13 days, respectively (Table 4).

In Cattleya hybrids, longevity of cellophane paper packing of fully open florets ranges from 14 to 45 days over unpacked florets i.e. 7 to 11 days.

In Phalaenopsis hybrids, longevity of cellophane paper packing of fully open 
florets ranges from 14 days (Phal. 'Boston' ) to 33 days (Phal. 'Ox Plum Rose x Black Jack').

\section{Enhancement of keeping quality of loose florets of orchids}

Out of seven treatments of $\mathrm{Al}_{2}\left(\mathrm{SO}_{4}\right)_{3}, 0.1$ to $1.0 \%$ was found best in Bamboo orchid, 0.1 to $0.4 \%$ in Epidendrum, 0.8 to $1.0 \%$ in Phalaenopsis and 0.4 to $0.6 \%$ in Cymbidium for enhancement of keeping quality of loose florets of orchids.

\section{Flower drying in orchids}

Embedded drying with borax and silica gel at $55^{\circ} \mathrm{C}$ in oven was found successful Coelogyne flaccida, Coelogyne cristata, Dendrobium nobile, Dendrobium williamsonii, Dendrobium aphyllum, Den, 'Erika', Den. 'Big White 4N', Den. 'Bangkok Blue', Paphs.'Nagasaki' and Cym. 'Sungold'.

Embedded drying with borax at $50^{\circ} \mathrm{C}$ in oven was found successful in Vanda teres, Dendrobium moschatum, Arundina graminifolia, Den. 'Madam Pink', Den. 'Lervia', Den. 'Abraham', Phal. 'Casa Blanca', Phal. 'Detroit' and Oncidium 'Sweet Sugar' and embedded drying with borax at $60^{\circ} \mathrm{C}$ was found successful in Epidendrum spp., Cattleya bowringiana and Cattleya hybrids, Phal. 'Ox Plum Rose x Black Jack' and Den. 'Big White'.

Under room condition $\left(24-25^{\circ} \mathrm{C}\right.$ and 75 $79 \% \mathrm{RH})$, perlite can be used for drying of spikes and florets of orchids within 15 to 20 days.

Embedded drying with borax and silica gel at $45-55^{\circ} \mathrm{C}$ was found successful Den. Thongchai Gold, Bangkok Blue, Paphiopedilum, Vanda, Phalenopsis 'Detroit', Buenos Aires' Plumeria, Hydrangea, Gladiolus and Lilium.

Embedded drying with borax at $50^{-} 60^{\circ} \mathrm{C}$ was found successful in Phal. 'Nagasaki, 'Manchester', 'Boston', 'Detroit', Den. 'Emma White', 'Lervia', 'A. Abraham', 'Triple Pink', Epidendrum spp. and Cym. 'Valley Teaser', 'N. Cherry', 'Bartha Peterson', and 'Platinum Gold'. Embedded drying with silica gel with best success has been reported by Dhatt et al, 2007; Desh Raj and Gupta, 2003.

Under room condition $\left(25-28^{\circ} \mathrm{C}\right.$ and $60 \%$ $\mathrm{RH})$, perlite, perlite + borax and perlite + silica gel were found successful for drying florets of Phalenopsis, Cattleya Dendrobium and Oncidium orchids.

\section{Economics of packaging technology}

Yield of spikes varies from genus to genus and variety to variety. A healthy well grown Cymbidium orchid will produce flowers spikes every year and a plant 10 years old can produce from 10 to 20 flower spikes. On an average, 6-8 spikes are available from commercial varieties of Dendrobium. Pricing of spikes depends upon the type of orchid and the grade of spikes. The cost of one Dendrobium spike ranges from Rs. 10 to Rs. 25 depending upon the grade. For Cymbidium, the cost of one spike ranges from Rs.100/- to Rs.200/-. The benefit cost ratio of packaging of Cymbidium ranges from 1.0 in spikes to 1.5 in florets whereas in Dendrobium benefit cost ratio of packaging of spikes is 0.67 .

\section{References}

De L.C., Vij S.P., Medhi R. P. 2014. PostHarvest Physiology and Technology in Orchids. J Horticulture, 1: 102. doi:10.4172/horticulture.1000102.

De LC. 2015. Commercial orchids. Berlin: De Gruyter Open. Available at: http://www.degruyter.com/view/product /456245

Dhatt KK, Singh Kushal and Ramesh Kumar. 
2007. Studies on methods of dehydration of rose buds. Journal of Ornamental Horticulture, 10(4): 264267.

Desh Raj and Gupta Prashant, K.2003. Standardizing dehydration technology for ornamental plant parts of shrubs from mid-hills of Himachal Pradesh. Journal of Ornamental Horticulture, 6(4): 357-361.

Flora Holland. 2015. Facts \& figures. FloraHolland facts and figures 2015. Available at: https://www.royalfloraholland. com/media/5685262/Royal Flora Holland_Annual_Report_2015_ENG_fa cts_and_figures.pdf.

Govaerts R., Bernet P., Kratochvil K., Gerlach G., Carr G., Alrich P, Pridgeon A.M., Pfahl J., Campacci M.A., Holland Baptista D., Tigges H., Shaw J., Cribb P., George A., Kreuz K. and Wood J.J. 2017. World checklist of Orchidaceae. Kew: Facilitated by the Royal Botanic Gardens. Available at: http://apps.kew.org/wcsp/ (accessed 23 March 2017).

Hanks F. 2015. Orchid cut flower industry. Report for the UK Agriculture and Horticulture Development Board and National Cut Flower Centre. Available at: https://horticulture. ahdb.org.uk sites/default/files/u3089/A\%20review\% 20 of $\% 20$ cut-flower $\% 20$ and $\% 20$ foliage $\% 20$ production $\% 20$ statistics $\% 202015$ 0 . pdf

Ketsa S., Uthairatanakij A. and Prayurawong
A. 2001. Senescence of diploid and tetraploid cut inflorescences of Dendrobium 'Caesar'. Scientia Hort,, 91: 133141.

Kumar, K. Madhu and Sheela, V.L. 2007. Status of breeding in orchids-A review. Journal of Ornamental Horticulture, 10: 199-208.

Leslie C.A., and Romani, R.J., 1986, Salicylic acid-a new inhibitor of ethylene biosynthesis, Plant Cell Report, 5: 144146

Lopez, R. G. and Runkle. E.S. 2005. Environmental physiology of growth and flowering of orchids. Hort. Science, 40(7): 1969-73.

Thammasiri K. 2015. Current status of orchid production in Thailand. In: Uthairatanaki A, Wannakrairoj S, eds. Acta Horticulturae, Vol. 1078. Leuven: International Society for Horticultural Science, (ISHS).25-33.

UNEP-WCMC. 2017. CITES trade statistics derived from the CITES Trade Database. Cambridge: UNEP World Conservation Monitoring Centre. Available at: https://trade.cites.org

Van Doorn W.G., de Stigter H.C.M. de Witte Y. and Boekestein A., 1991b. Microorganisms at the cut surface and in the xylem vessels of rose stems: a scanning electron microscope study, Journal of Applied Bacteriology, 70: 34-39

Willis K.J. (ed) .2017. State of the world's plants 2017. Report. Royal Botanic Gardens, Kew.

\section{How to cite this article:}

De, L. C. 2020. Post-harvest Management of Orchid Spikes and Florets. Int.J.Curr.Microbiol.App.Sci. 9(09): 2624-2638. doi: https://doi.org/10.20546/ijcmas.2020.909.328 